\title{
ILSE STORCH
}

\section{Habitat and survival of capercaillie Tetrao urogallus}

Nests and broods in the Bavarian Alps 


\title{
HABITAT AND SURVIVAL OF CAPERCAILLIE Tetrao urogallus NESTS AND BROODS IN THE BAVARIAN ALPS
}

\author{
Ilse Storch \\ Institute of Wildlife Research and Management, University of Munich, Hohenbachernstr. 22, D-85354 Freising, and Munich Wildlife \\ Society, Linderhof 2, D-82488 Ettal, Germany
}

(Received 14 July 1993; revised version received 28 January 1994; accepted 16 February 1994)

\begin{abstract}
The capercaillie Tetrao urogallus has become endangered in central Europe, most probably as a result of habitat changes. Breeding ecology was studied by following radio-tagged hens through egg-laying, incubation, and chick-rearing between 1988 and 1992. Loss of chicks rather than nests was the main determinant of reproductive success. All adult hens incubated, two-thirds of the nests hatched, and one-fifth of the chicks survived until autumn. Both nests and broods were mostly found in habitats with rich ground vegetation. Nest cover was probably a major factor for hatching success. Brood home ranges averaged 148 ha during the period from hatching to late summer. Broods preferred old forest stands with rich ground vegetation and high invertebrate abundance, which occur under moderate canopy cover. Bilberry Vaccinium myrtillus was an essential feature for brood habitat at forest stand, home range, and landscape scale, and should therefore be a major goal for capercaillie habitat management in central Europe.
\end{abstract}

Keywords: Alps, breeding ecology, habitat selection, Tetrao urogallus, Vaccinium myrtillus, survival.

\section{INTRODUCTION}

During the last few decades, capercaillie Tetrao urogallus numbers have markedly declined in most of its range. In central Europe, the species is highly endangered, and numerous local populations have disappeared. Loss and deterioration of habitats have been assumed to be the major causes (see review in Klaus et al., 1986). Changes in reproductive success, i.e. the production and survival of young, may have led to the population decline observed (e.g. Klaus, 1985; Klaus et al., 1986). Changes in capercaillie breeding success are mostly ascribed to extrinsic factors, mainly climate, insect availability, and predators. Predation is frequently the proximate cause of mortality (Marcström et al., 1988; Kastdalen \& Wegge, 1991; Storch \& Willebrand, 1991). However, factors are likely to act in concert, since resource availability and predation risk may vary in time and space due to habitat and weather conditions.

Capercaillie conservation in central Europe is built on high ambitions but a poor database. Our knowledge has traditionally been focused on males in the display season. Studies into habitat relationships of breeding hens and of broods are lacking, despite their importance for conservation. The objective of this study was to fill these gaps. In this paper, I describe habitat, range use, and survival of capercaillie nests and broods from the Alps, based on radio-tagged hens, and discuss implications for conservation.

\section{STUDY AREA}

The study area was Teisenberg, a $50 \mathrm{~km}^{2}$ mountain range of the foothills of the Bavarian Alps, Germany. Elevations vary between 700 and $1800 \mathrm{~m}$. The lower slopes $(<1000 \mathrm{~m})$ include $51 \%$ of the area; $42 \%$ belong to the upper slopes $(1000-1300 \mathrm{~m})$, the range with the best bilberry Vaccinium myrtillus cover (Storch, 1993a). Only $7 \%$ of the area is above $1300 \mathrm{~m}$ altitude. The climate is moist and temperate with mean annual temperatures of $5^{\circ} \mathrm{C}$ and precipitation of $1800 \mathrm{~mm}$. July is the warmest month $\left(14.5^{\circ} \mathrm{C}\right)$, and June and July the wettest (1989-1991: June 134-266 mm, July 196-292 mm). The main tree species was Norway spruce Picea abies (70\%) mixed with fir Abies alba $(10 \%)$ and beech Fagus sylvatica $(15 \%)$. Stands of varying ages formed a forest mosaic with patches of $1-100$ ha. Canopy height reached $30 \mathrm{~m}$. Bilberry dominated the understorey in the central part of the area, otherwise grasses prevailed. Teisenberg held 100-200 capercaillie, and exchange with populations in adjacent mountain ranges was regularly observed. Among potential predators of nests and chicks, red fox Vulpes vulpes, European badger Meles meles, pine marten Martes martes, goshawk Accipiter gentilis, and corvids Corax corax and Garrulus glandarius were common.

\section{METHODS}

\section{Habitat features}

Forest stands on Teisenberg were mostly even-aged. Habitat patches ( $\geq 1$ ha; $n=558$ ) were distinguished by successional stage: clearcuts (cleared areas covered by natural regeneration; $c$. $0-10$ years old), thickets (young forest before thinning; $c$. 10-20 years), pole stage (young forest after first thinning; c. 20-50 years), middle-aged forest (after second thinning, mean canopy cover 70\%; c. 50-90 years), and old forest (final felling 
stage, mean canopy cover $56 \%$; $\geq 90$ years). In the summers of 1989 and 1990, habitat structure was recorded within a total of 4500 random plots (radius $10 \mathrm{~m}, c .1$ plot per ha). At least three random plots were sampled per patch, and the mean values of the plots sampled were used to describe the patches. A habitat map was created using a geographical information system.

Habitat fragmentation was assessed by patch size (ha) and by the amount of edge $(\mathrm{m} / \mathrm{ha}$ ) per forest stand, which was estimated from aerial photographs (1 $: 10,000)$ and included boundaries between old or middle-aged stands and clearcuts or thickets respectively, plus trails and forest roads ( $>10 \mathrm{~m}$ wide), and gaps $(>0.1 \mathrm{ha})$ within the stand. Measures of habitat structure included the number of distinct vegetation layers (one or two tree layers, shrub layer, field layer), and cover and composition ( $\%$ of total cover estimated to the nearest $10 \%$ ) of the tree and field layers. The ground vegetation types distinguished were mosses Bryophyta, ferns Pteridophyta, bilberry, raspberry Rubus spp., regeneration (trees $<1 \mathrm{~m}$ height), and others (other herbaceous plants). Diversity of the tree and field layers was calculated by the Shannon-Wiener index (Krebs, 1989) based on tree species composition and ground vegetation types, respectively.

As an estimate of chick food availability, invertebrate abundance in the ground vegetation was measured in relation to canopy cover at 81 sites. These were divided among four forest stages (30 in clearcuts, five in pole stage, 15 in middle-aged, 31 in old forest), in each case with approximately equal numbers of grass-dominated $(n=37)$ and bilberry-dominated ( $n=$ 44) sites on NE-exposed slopes at $1100 \mathrm{~m}$ altitude. Catches were counted in five sweep-net samples per site taken on 10 July 1991. Abundance of anthills within forest stands was expressed as the proportion of random plots with anthills.

\section{Radio tracking}

Using mist nets in autumn habitats and at leks in spring, 16 capercaillie hens were caught and equipped with $28 \mathrm{~g}$ necklace transmitters. Two juveniles $(<1$ year) were distinguished by shape and pigmentation of the outer primaries (Helminen, 1963). The tagged birds were located once or twice a day to determine the start of incubation. The nest site was visited once before hatching, usually without flushing the hen.

Broods of tagged hens were located daily, and mostly from a distance of $<500 \mathrm{~m}$. Three to five bearings were taken per fix; locations with error polygons $>1$ ha were excluded. The dataset included 215 locations from nine broods tracked between June and August 1988-1992. Brood home ranges were estimated as convex polygons. As an index to brood movements, distances were measured between locations taken on consecutive days, i.e. at intervals of $c .24 \mathrm{~h}$.

\section{Survival of nests and broods}

In order to detect nest losses during incubation, the presence of the hen at the nest was checked by telemetry at intervals of 1-2 days. When a hen was repeatedly located off the nest, the nest was checked. Clutch size was counted when the hen was off the nest, or only after hatching. Two nests that were robbed before they were recorded were assumed to have the mean clutch size.

Chick survival was expressed as the proportion of chicks still with the radio-tagged hens at various intervals after hatching, as estimated from weekly direct observations. If a count gave a higher number of chicks than the previous count the latter was corrected.

\section{Habitat use}

Analysis of nest site selection was based on 14 radiotagged hens, plus four nests found by chance during habitat mapping (Storch, 1991). Nest sites were described by successional stage, stand size $(<10$ ha, $10-20$ ha, $>20 \mathrm{ha})$, and by the distance of the nest from an edge $(0-25 \mathrm{~m}, 25-75 \mathrm{~m},>75 \mathrm{~m})$. For 12 nests of radiotagged hens, nest cover was classified as complete or incomplete, depending on whether or not the hen was camouflaged by vegetation from all sides when viewed from a distance of $2.5 \mathrm{~m}$.

Habitat selection by broods was analysed stepwise at different spatial scales. As differences in habitat selection by young (June-July) versus older (August) broods were not significant, all data were pooled. At the landscape level, the distribution of radio locations was compared to availability of altitude ranges within the Teisenberg area.

Home range selection was analysed for six broods which survived through August, comparing the proportions of successional stages and of ground vegetation types in home ranges and in the study area (Wilcoxon signed-rank matched-pair test). The utilization (U) of old forest was calculated for each brood as the frequency of radio locations in old forest, and availability (A) as the proportion of old forest within the home range. To evaluate selection of bilberry within home ranges, $U$ was calculated as the mean proportion of bilberry cover in the field layer at brood locations, and $A$ as the mean proportion of bilberry in the home range. Ivlev's electivity index (Krebs, 1989) was calculated as $\mathrm{I}=$ $(U-A) /(U+A)$, and the observed electivity scores were tested for random utilization of old forest stands and presence of bilberry ( $\mathrm{I}=0$; Wilcoxon signed-rank matched-pair test).

To analyse habitat use at forest stand level, the distribution of radio locations was compared with habitat availability, which was estimated by a set of 2500 random points distributed over the habitat map of the study area (Mann-Whitney U-tests).

Statistical tests were two-tailed throughout.

\section{RESULTS}

\section{Nesting habitat}

Habitat distribution of nests differed significantly from expectation in relation to successional stage and distance to an edge, but not in relation to stand size. Clearcuts (with nine nests) and old forest (seven nests) were pre- 

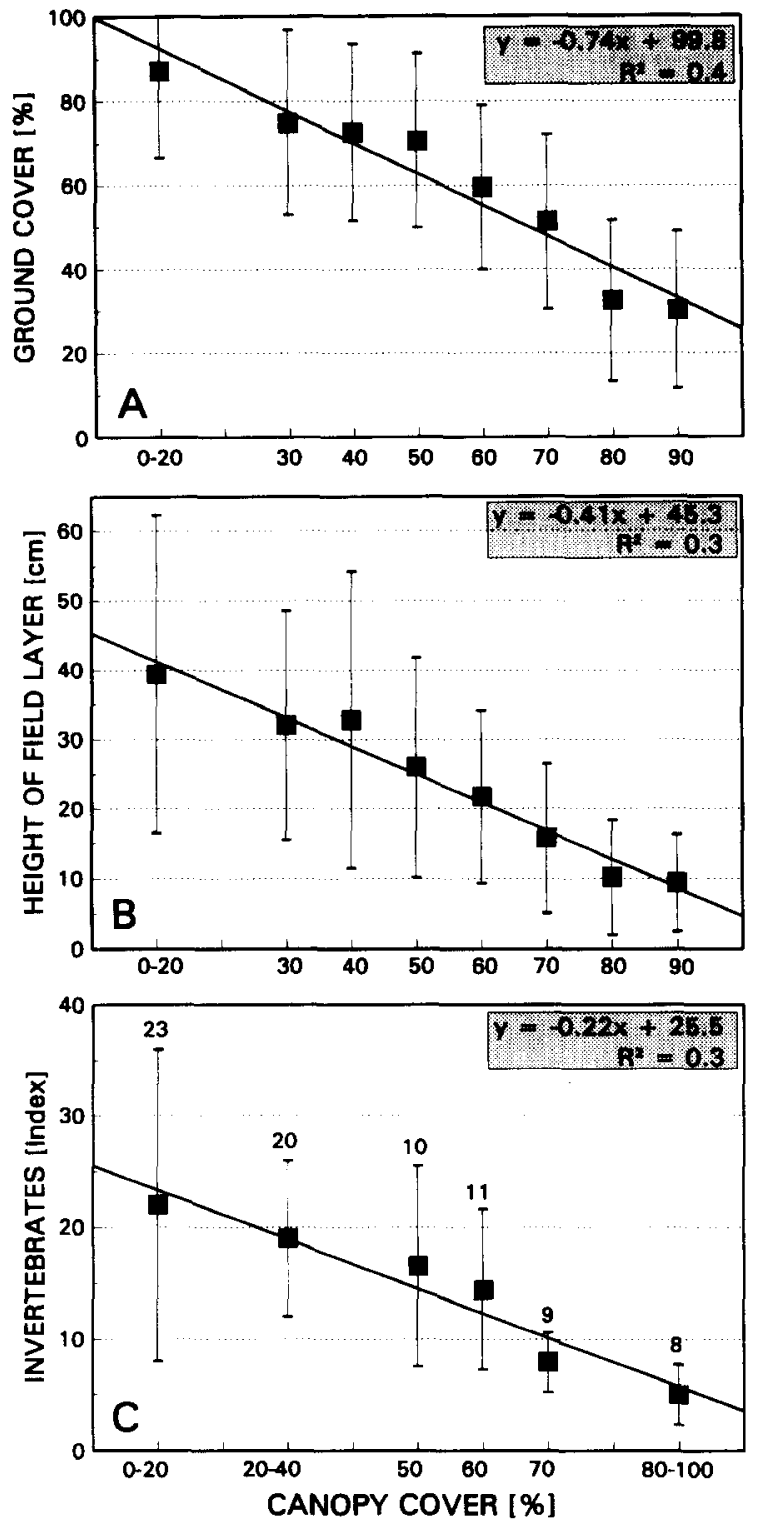

Fig. 1. Relation between canopy cover, ground cover (A) and height of the field layer (B) $(\bar{x} \pm S D$; calculated from 2500 random points distributed over the habitat map), and invertebrate abundance ( $C$; index; $\bar{x} \pm \mathrm{SD}, n$ plots sampled) on Teisenberg, Bavarian Alps.

ferred to other seral stages (two nests) $\left(\chi^{2}=24 \cdot 2\right.$, d.f. $=$ $1, p<0.001)$. In 15 cases, hens selected nest sites within $25 \mathrm{~m}$ from an edge, while the other three were between 25 and $75 \mathrm{~m}$. For 12 radio-tagged hens, eight nests were sheltered from above by small trees, two by other vegetation, and two nests were at the trunks of tall trees. Cover and height of the field layer were inversely related to canopy closure (Fig. 1), so better nest cover was available along old forest edges than within old forest stands.

\section{Survival of nests and broods}

All 14 adult tagged hens incubated but two juveniles gave no indication of nesting, and were very mobile throughout June. Dates for the start of incubation were normally distributed between 9 May and 20 June with a mean date of 29 May. The mean clutch size for 12 nests was $6 \cdot 4 \pm 1 \cdot 1 \mathrm{SD}$.

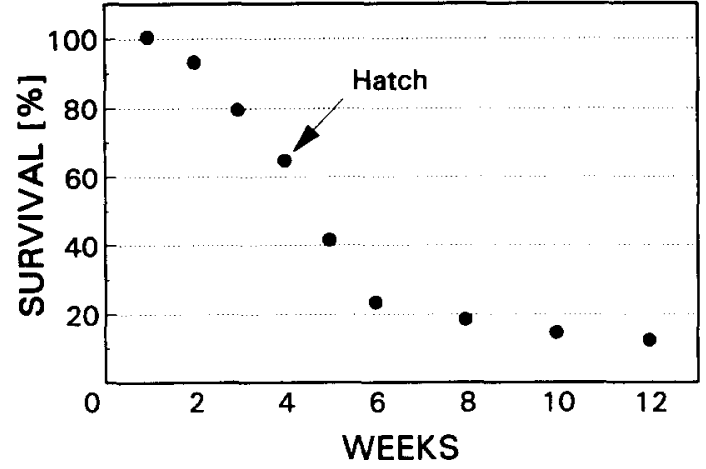

Fig. 2. Survival of capercaillie eggs and chicks from 14 clutches from the start of incubation, in relation to the total number of eggs laid $(n=90)$.

Nine nests were successful so that, from a total of 90 eggs incubated, 56 chicks (62\%) hatched (Fig. 2). Two eggs in the same clutch failed because of early death of the embryos, and one clutch failed because the hen was killed by a predator when off the nest. All other losses were due to nest predation, but hens survived. Chicks hatched between 4 June and 9 July with a mean date of 25 June. Nest survival appeared to be related to nest cover: seven nests with complete cover were successful, but three out of five with incomplete cover failed $(p=$ 0.045; Fisher's exact test).

Broods suffered high initial losses with only $38 \%$ of the chicks surviving the first two weeks, but in late August $20 \%$ of the chicks were still alive (Fig. 2). When all chicks were lost, hens typically moved about $1 \mathrm{~km}$ to a distinct part of their range within a day and therefore total brood losses could be reliably noted. All three total brood losses occurred during the first two weeks of life, and coincided with periods of severe rainfall.

\section{Habitat and range use by broods}

Broods left the nest shortly after hatching, and within the first two months of their life daily distances moved increased with age (Fig. 3). By late August, they had

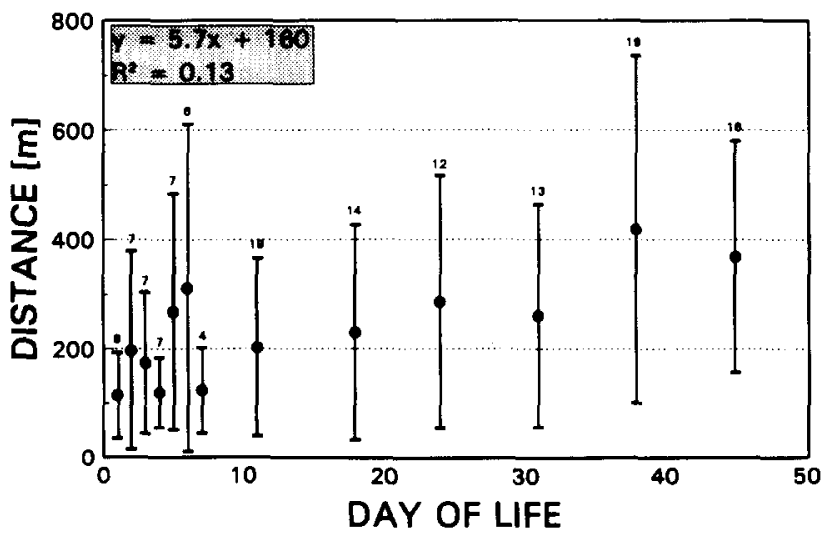

Fig. 3. Daily movements of broods in relation to age, as measured by the distance between locations in consecutive days $(\vec{x} \pm \mathrm{SD})$. For the first week, daily values are given; for older broods, data were pooled per week ( $n$ brood days is given above columns). 
Table 1. Aspects of range use by capercaillie broods, 1989 1992

\begin{tabular}{lccrrr}
\hline \multicolumn{1}{c}{ Measure } & Range & $n$ & $\bar{x}$ & SD Median \\
\hline Distance from nest [m] & & & & & \\
$\quad$ After 1 day & $30-270$ & 8 & 115 & 79 & 100 \\
$\quad$ After 1 week & $40-1100$ & 7 & 334 & 355 & 300 \\
$\quad$ After 3 weeks & $100-1000$ & 5 & 643 & 334 & 720 \\
$\quad$ Maximum (to late August) & $800-1800$ & 6 & 1172 & 370 & 1025 \\
Brood home range size [ha] & & & & & \\
$\quad$ Weeks 1-2 & $5-50$ & 7 & 24 & 19 & 25 \\
$\quad$ Weeks 1-4 & $20-140$ & 5 & 70 & 46 & 60 \\
To late August & $75-343$ & 6 & 148 & 106 & 85 \\
\hline
\end{tabular}

usually moved more than $1 \mathrm{~km}$ away from the nest and the home range averaged 148 ha (Table 1).

All locations of tagged broods were on the upper slopes between 1000 and $1300 \mathrm{~m}$. Habitat availability was therefore considered with respect to the upper slopes only in the further analyses ( $7 \%$ of the area were clearcuts, $13 \%$ thickets, $20 \%$ pole stage, $30 \%$ middleaged, and $17 \%$ old forest).

All radio-tagged broods used home ranges with more old forest and greater bilberry cover than expected from availability in the area; within home ranges all broods preferred old forest and locations rich in bilberry $(p<$ 0.05 for all tests (Fig. 4). Availability of other vegetation types within home ranges was not significantly different from expectation. At forest stand level, broods preferred
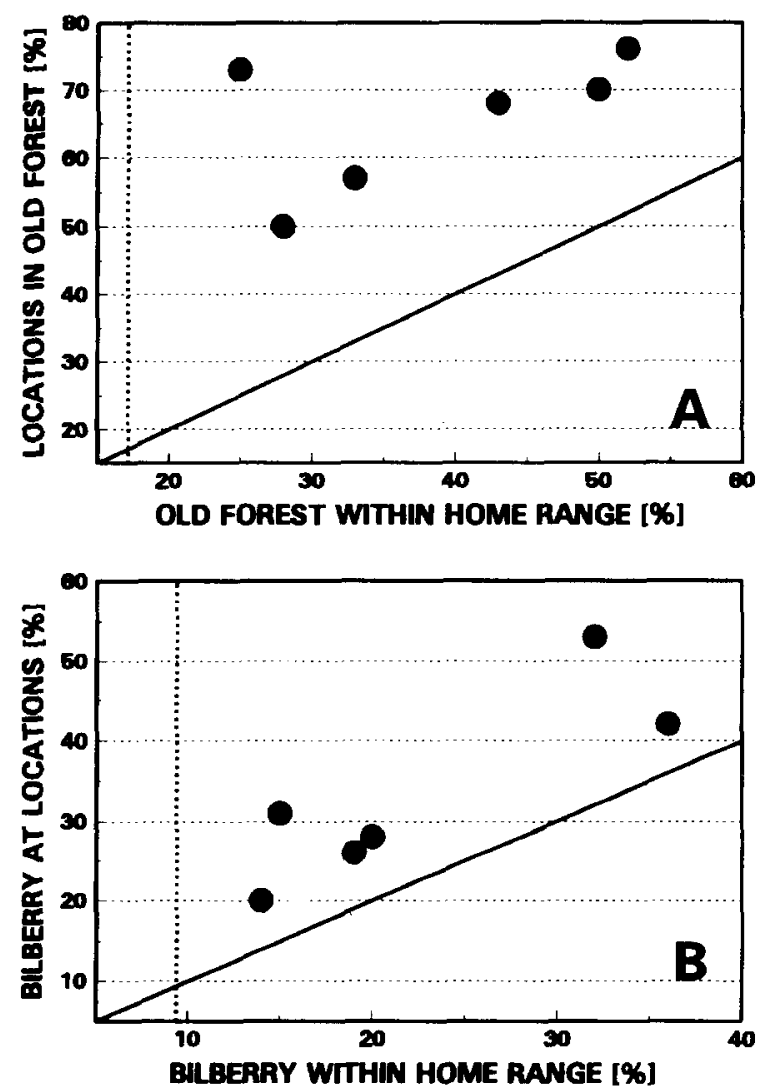

Fig. 4. Habitat use by broods $(n=6)$ in relation to availability of old forest (A) and mean bilberry cover in the field layer (B) within home ranges. The dotted lines indicate availability within the study area, the solid lines random use of habitats within the home range.
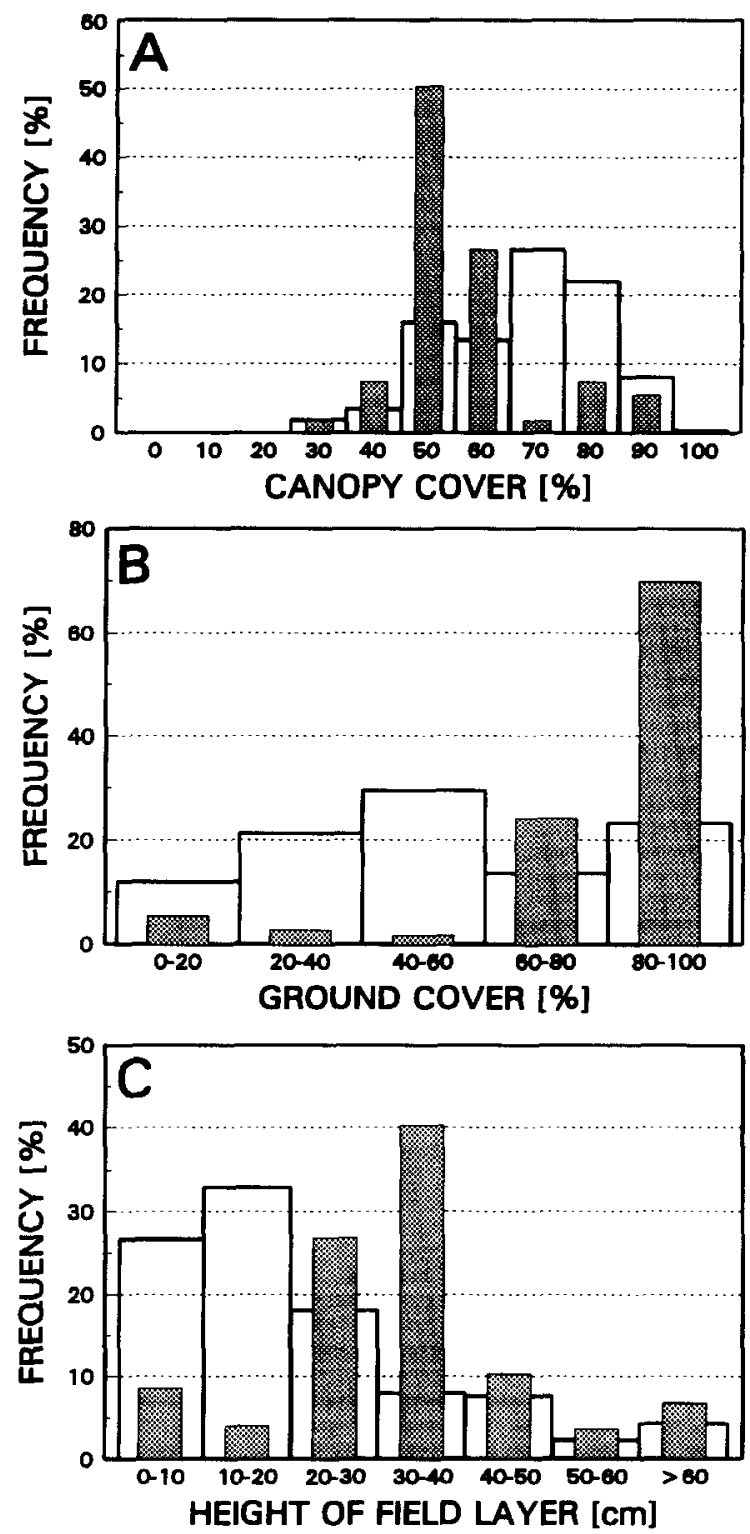

Fig. 5. Distribution of brood locations (dark columns) in relation to canopy cover (A; $n=165$ locations; pole and older forest stages combined), ground cover (B; $n=215$ locations) and height of the field layer ( $\mathrm{C} ; n=215$ locations) on Teisenberg (open columns).

habitats with moderate canopy cover, high ground cover, medium vegetation height (Fig. 5), and anthills (Table 2). These features were best represented in old forest. Old forest stands used by broods substantially differed from availability only with regard to bilberry cover (Table 2).

Invertebrate abundance was negatively related to canopy cover (Fig. 1), and was not different between old forest and clearcuts, which had more invertebrates than had pole stage and middle-aged forest stands $(F=$ 8.6 , d.f. $=3, p<0.05$, ANOVA, Duncan test). Sweepnetting underestimated invertebrate abundance in bilberry-dominated vegetation, because shrubs taller than $30 \mathrm{~cm}$ such as on Teisenberg are much more resistant to sweeping than are grasses. Therefore, conclusions about invertebrate abundance in relation to vegetation types were not possible. The occurrence of anthills was correlated with bilberry cover $\left(\mathbf{R}^{2}=0.11 ; p<0.001\right)$. 
Table 2. Habitat selection by nine capercaillie broods within all forest stages and within old forest Utilization $(\bar{x} \pm$ SE) was calculated from 215 radio locations in all forest stages and 109 in old forest, availability $(\bar{x} \pm$ SE) relates to the upper slopes of Teisenberg.

\begin{tabular}{|c|c|c|c|c|}
\hline \multirow[t]{2}{*}{ Habitat factor } & \multicolumn{2}{|c|}{ All forest stages } & \multicolumn{2}{|c|}{ Old forest } \\
\hline & Availability & Utilization & Availability & Utilization \\
\hline \multicolumn{5}{|c|}{ Tree layer (pole stage and older) } \\
\hline$\%$ canopy cover & $67 \cdot 2 \pm 0.5$ & $56.6 \pm 1.0$ & $53.7 \pm 0.9$ & $50.8 \pm 0.7$ \\
\hline$\%$ spruce & $88 \cdot 1 \pm 0.7$ & $94 \cdot 1 \pm 0.7$ & $84.6 \pm 1.5$ & $93.6 \pm 0.8$ \\
\hline$\%$ fir & $3.7 \pm 0.4$ & $3.8 \pm 0.5$ & $6.7 \pm 0.9$ & $3.7 \pm 0.4$ \\
\hline$\%$ beech & $7 \cdot 3 \pm 0.6$ & $1.7 \pm 0.2$ & $7 \cdot 5 \pm 1.2$ & $2.2 \pm 0.3$ \\
\hline Tree species diversity & $0.4 \pm 0.04$ & $0.2 \pm 0.2$ & $0.4 \pm 0.03$ & $0.2 \pm 0.03$ \\
\hline \multicolumn{5}{|l|}{ Field layer (all forest stages) } \\
\hline$\%$ ground cover & $54 \cdot 3 \pm 2 \cdot 0$ & $80.8 \pm 1.5$ & $83 \cdot 4 \pm 1 \cdot 2$ & $90 \cdot 2 \pm 0.8$ \\
\hline Height of field layer $(\mathrm{cm})$ & $20 \cdot 6 \pm 1 \cdot 3$ & $32 \cdot 2 \pm 1 \cdot 0$ & $30 \cdot 7 \pm 1 \cdot 1$ & $34 \cdot 0 \pm 1 \cdot 0$ \\
\hline$\%$ moss & $17 \cdot 4 \pm 1 \cdot 5$ & $7.8 \pm 1 \cdot 1$ & $6.5 \pm 0.7$ & $5.9 \pm 0.6$ \\
\hline$\%$ fern & $17 \cdot 8 \pm 1 \cdot 2$ & $14.3 \pm 0.9$ & $14.8 \pm 0.8$ & $13 \cdot 4 \pm 1 \cdot 1$ \\
\hline$\%$ grass & $22 \cdot 2 \pm 1 \cdot 6$ & $27 \cdot 1 \pm 1.4$ & $27.6 \pm 1.8$ & $30.9 \pm 1.9$ \\
\hline$\%$ bilberry & $9 \cdot 4 \pm 1 \cdot 3$ & $30 \cdot 4 \pm 1.7$ & $21 \cdot 2 \pm 2 \cdot 0$ & $35 \cdot 2 \pm 2 \cdot 5$ \\
\hline$\%$ raspberry & $4.5 \pm 0.6$ & $2.5 \pm 0.3$ & $5.2 \pm 0.6$ & $1.8 \pm 0.3$ \\
\hline$\%$ regeneration & $1.0 \pm 0.2$ & $1.3 \pm 0.2$ & $2 \cdot 2 \pm 0 \cdot 3$ & $1.2 \pm 0.2$ \\
\hline$\%$ other vegetation & $27.9 \pm 1.8$ & $14.7 \pm 1.0$ & $22.5 \pm 1.6$ & $11.6 \pm 0.9$ \\
\hline Diversity & $1.2 \pm 0.06$ & $1 \cdot 1 \pm 0.02$ & $1.2 \pm 0.02$ & $1.2 \pm 0.02$ \\
\hline Patch size (ha) & & & $9.9 \pm 0.5$ & $11.4 \pm 0.7$ \\
\hline Edge $(\mathrm{m} / \mathrm{ha})$ & & & $160 \pm 7 \cdot 1$ & $152 \pm 8.6$ \\
\hline Vegetation layering & & & $2.2 \pm 0.03$ & $2.2 \pm 0.02$ \\
\hline Occurrence of anthills (\%) & $4.8 \pm 0.7$ & & $9 \cdot 1 \pm 1 \cdot 0$ & $17.5 \pm 1.7$ \\
\hline
\end{tabular}

\section{DISCUSSION}

\section{Nesting habitat}

Nest site selection may primarily relate to predator avoidance (Bergerud \& Gratson, 1988). On Teisenberg, capercaillie nests are typically placed at the edge between old forest and clearcuts where there is particularly good ground cover. An experiment with dummy nests showed that these may be the habitats with the lowest risk of nest predation (Storch, 1991). Records from Russia also show that capercaillie prefer to nest in edge habitats (Semenov-Tjan-Sanskij, 1960, cited in Klaus et al., 1986). Scandinavian results are ambiguous: although capercaillie were found to nest mostly in clearcuts or old forests, no preference was reported for edge habitats, nor was a significant relationship found between nest cover and survival (Storaas et al., 1982; Storaas \& Wegge, 1987). Variation in habitat structure and/or predator species may explain the differences observed.

\section{Survival of nest and broods}

Both nests and broods have been reported to suffer severe losses, but as in other grouse their relative importance for reproductive success may vary (Storch \& Willebrand, 1991). The Teisenberg sample of hens and nests was limited so results should be interpreted with caution, but they indicate that chick rather than nest loss was the major determinant of reproductive success.

Yearly nest losses in capercaillie can vary considerably from less than 20\% (Höglund, 1952) to $90 \%$ (Wegge \& Storaas, 1990). Studies in Scandinavia (Wegge \& Grasaas, 1977) and central Europe (Klaus, 1985) suggest that nest losses have increased in recent decades as a consequence of habitat changes, and may be an important factor in the population declines observed. On Teisenberg, nest losses were rather low compared to other recent reports. Wild boar Sus scrofa, the main cause of nest destruction in other parts of central Europe (Klaus, 1985; Müller, 1985), do not occur here, and crows Corvus spp., which are major predators of grouse nests in Scandinavia (e.g. Andrén, 1989), were almost never seen.

The high chick mortality on Teisenberg was probably due to climatic factors, especially rainfall during the first two weeks of life (e.g. Slagsvold \& Grasaas, 1979; Moss, 1985; Moss \& Oswald, 1985; Kastdalen \& Wegge, 1991). In the Bavarian Alps, periods of several days of almost continuous rainfall occur in June and July in most years. However, as hatching occurs over several weeks, it is unusual for all broods to be hit by rainy periods during their first two weeks.

\section{Habitat and range use by broods}

Grouse broods commonly leave the surroundings of the nest shortly after hatching. One possible explanation is poor interspersion of nesting and brood-rearing habitats (Bergerud \& Gratson, 1988) but distinct habitat requirements of nests and broods were not evident on Teisenberg. By late August home range size was similar to figures reported from Norway (Wegge et al., 1982). Broods mostly stayed within a kilometre of the nest throughout summer. Distances between daily locations varied considerably, as was described earlier for capercaillie (Wegge et al., 1982; Barikmo et al., 1985) and other galliforms (Southwood \& Cross, 1969; Erikstad, 1985). Mobility may present an adaptation for 
predator avoidance. Alternatively, movements may be inversely related to factors of habitat quality, e.g. insect availability (Bergerud \& Gratson, 1988).

Invertebrates constitute a major portion of the diet of galliform chicks. Young capercaillie chicks were found to consume about $80 \%$ invertebrates, and select habitats with high invertebrate abundance (Börset \& Krafft, 1973; Kastdalen \& Wegge, 1985). Ants are regularly eaten by chicks and are frequently assumed to be critical to brood habitat, particularly in the central European literature (e.g. Glutz v. Blotzheim, 1973; Müller, 1974; Klaus et al., 1986). The proportion in the diet varies among studies (Kastdalen \& Wegge, 1985; Spidsö \& Stuen, 1988) and was not known on Teisenberg, but broods and single adults used habitats rich in anthills (Storch, 1993a). In adult capercaillie from Teisenberg, ants remained a minor component of the diet (Schwarzmüller, 1990). As occurrence of anthills and bilberry were intercorrelated, the strong preference for bilberry-rich ground vegetation may be the primary explanation for the frequent occurrence of anthills in capercaillie habitats. The availability of preferred invertebrate food, such as caterpillars (Kastdalen \& Wegge, 1985), varies with weather conditions, but anthills are a constantly available food source. Thus, ants may present an important resource when other insects are scarce and may play a role in brood survival.

As chicks grow older, vegetative matter, and especially bilberry - the preferred food of adults-gains importance in the diet (Spidsö \& Stuen, 1988; Storch et al., 1991). Bilberry supports higher arthropod densities than grass (Kastdalen \& Wegge, 1985; Stuen \& Spidsö, 1988; Biedermann, 1992) and thus provides both optimal plant and animal food for chicks. It also provides cover against predators, and probably a favourable microclimate as, unlike grasses, it withstands wind and rainfall. This may explain why bilberry was the major factor in habitat selection by broods at landscape, home range, and forest stand level. Other factors, such as vegetation diversity and layering, which are often stated to be vital to capercaillie habitats in central Europe (e.g. Klaus et al., 1985, 1986), seem to be negligible as long as bilberry cover is provided.

Compared to the boreal zone, luxuriant bilberry cover is rare in central European forests and a decline is being observed due to eutrophication of forest soils from polluted rain and air (Porkert, 1982; Ellenberg, 1983, 1992; Klaus et al., 1985). Loss and deterioration of bilberry habitats may lead to reduced brood survival and thus to population decline.

\section{Implications for capercaillie conservation}

In most of the central European range of the capercaillie, conservationists are trying to improve the situation of the species by habitat management. It is often postulated that brood habitats in particular should be protected, implying distinct habitat requirements of broods and adults, although there is no thorough evidence. The Teisenberg study makes it clear that birds both with and without broods favour coniferous forest with rich bilberry cover. Furthermore, nests and broods occur throughout the area used by adults (Storch, 1993 $a, b, c$; this study).

Habitat management for capercaillie should aim to increase the amount of preferred habitat. Because of the birds' large spatial requirements (Storch, 1993a; this study), both local habitat structure and landscape mosaic should be considered. Thinning and the creation of edges and gaps will favour the field layer in dense forests; bilberry develops best in stands with canopy cover of about $50 \%$ (Storch, in press). Other factors which limit the growth of bilberry, such as browsing by deer, should be controlled. Foresters should neither use fertilizers, which favour the growth of grasses, nor insecticides. In order to protect nests, no cutting should be done along old forest edges between 1 May and 15 July.

Many central European capercaillie populations are small and isolated. As chick survival largely depends on weather conditions, small capercaillie populations are highly vulnerable and may not respond to habitat improvement. Therefore, habitat conservation should be initiated long before a population becomes in danger of extinction.

\section{ACKNOWLEDGEMENTS}

Thanks to all the students who helped tracking hens and broods. The comments by David Baines, Brian Davis, Ivar Gjerde, Leif Kastdalen, Jørund Rolstad, Tor Spidsø, and Per Wegge greatly improved the manuscript. Marlo Raynolds checked the English. Financial support was provided by the Bavarian State Ministry of Agriculture, and by IBM Germany.

\section{REFERENCES}

Andrén, H. (1989). Predation processes in fragmented boreal forest landscapes. $\mathrm{PhD}$ thesis, Uppsala University.

Barikmo, J., Osbak, P. \& Bökseth, O.-K. (1985). Distances of movements and spacing behaviour for capercaillie broods. Proc. Int. Symp. Grouse, 3, 291-7.

Bergerud, A. T. \& Gratson, M. W. (1988). Survival and breeding strategies of grouse. In Adaptive strategies and population ecology of northern grouse, Vol. II. Theory and Synthesis, ed. A. T. Bergerud \& M. W. Gratson. University of Minnesota Press, Minneapolis.

Biedermann, R. (1992). Arthropodenvielfalt und AuerhuhnNahrung in den emissionsgeschädigten Hochlagen des Bayerischen Waldes. Thesis, University of Regensburg, Germany.

Börset, E. \& Krafft, A. (1973). Black grouse and capercaillie brood habitats in a Norwegian spruce forest. Oikos, 24, 1-7.

Ellenberg, H. (1983). Gefährdung wildlebender Pflanzenarten in der Bundesrepublik Deutschland. Forstarchiv, 54, 127-33.

Ellenberg, H. (1992). Eutrophication and its consequences for habitat, species and conservation. Grouse News, 3, 5-7.

Erikstad, K. E. (1985). Growth and survival of willow grouse chicks in relation to home range size, brood movements and habitat selection. Ornis Scand., 16, 181-90.

Glutz von Blotzheim, U. N. (ed.) (1973). Handbuch der Vögel Mitteleuropas, 5. Akademische Verlagsgesellschaft, Frankfurt am Main. 
Helminen, M. (1963). Composition of the Finnish population of capercaillie and black grouse in the autumn of 1952-61, as revealed by a study of wings. Finnish Game Res., 23, 1-124.

Höglund, N. (1952). Capercaillie reproduction and climate. Pap. Game Res., 8, 78-80.

Kastdalen, L. \& Wegge, P. (1985). Animal food in capercaillie and black grouse chicks in south east Norway-a preliminary report. Proc. Int. Symp. Grouse, 3, 499-509.

Kastdalen, L. \& Wegge, P. (1991). Kyllingprosjektet 1986-1989. Om naturlig dödelighet blant storfuglkyllinger. (unpublished report) Norges Landbrukshögskole, Aas Norway.

Klaus, S. (1985). Predation among capercaillie in a reserve in Thuringia. Proc. Int. Symp. Grouse, 3, 33446.

Klaus, S., Boock, W., Görner, M., \& Seibt, E. (1985). Zur Ökologie des Auerhuhns in Thüringen. Acta Ornithoecol., 1, 3-46.

Klaus, S., Andreev, A. V., Bergmann, H.-H., Müller, F., Porkert, J. \& Wiesner, J. (1986). Die Auerhühner. Die Neue Brehm-Bücherei. Ziemsen Verlag, Wittenberg Lutherstadt.

Krebs, C. J. (1989). Ecological methodology. Harper \& Row, New York

Marcström, V., Kenward R. E. \& Engren, E. (1988). The impact of predation on boreal tetraonids during vole cycles: an experimental study. J. Anim. Ecol., 57, 859-72.

Moss, R. 1985). Rain, breeding success and distribution of capercaillie and black grouse in Scotland. Ibis, 128, 65-72.

Moss, R. \& Oswald, J. (1985). Population dynamics of capercaillie in a North-east Scottish glen. Ornis Scand., 16 , 229-38.

Müller, F. (1974). Territorialverhalten und Siedlungsstruktur einer mitteleuropäischen Population des Auerhuhns. PhD thesis, University of Marburg.

Müller, F. (1985). The loss of capercaillie clutches - an evaluation of a ten year study on simulated nests in the western Rhön mountains (W Germany). Proc. Int. Grouse Symp., 3, $347-50$.

Porkert, J. (1982). Zu den Veränderungen der Struktur der Rauhfusshühner-Biotope in den Kammlagen des Ostteils der Sudeten und ihres Zusammenhanges mit den im Niederschlagswasser transportierten Schadstoffimmissionen. Opera corcont., 19, 165-82.

Schwarzmüller, C. (1990). Nahrungswahl von Auerhühnern. Thesis, University of Munich.

Semenov-Tjan-Sanskij, O. I. (1960). Ökologie der Rauhfußhühner des Lapland-Naturschutzgebiets. Trudy Laplands. zapov., 1, 217-306 (in Russian).

Slagsvold, T. \& Grasaas, T. (1979). Autumn population size of the capercaillie in relation to weather. Ornis Scand., 10, $37-41$.
Southwood, T. R. E. \& Cross, D. J. (1969). The ecology of the partridge, III. Breeding success and the abundance of insects in the natural habitats. J. Anim. Ecol., 38, 497-509.

Spidsø, T. K. \& Stuen, O. H. (1988). Food selection by capercaillie chicks in southern Norway. Can. J. Zool., 66, $279-83$.

Spidsø, Wegge, P. \& Storaas, T. (1985. Renesting in capercaillie in southern Norway. Proc. Int. Symp. Grouse, 3, 278-88.

Storaas, T., Wegge, P. \& Larsen, B. B. (1982). Nest predation among capercaillie and black grouse as affected by habitat location and cover. Proc. Int. Grouse Symp., 2, 131-7.

Storaas, T. \& Wegge, P. (1987). Nesting habitats and nest predation in sympatric populations of capercaillie and black grouse. J. Wildl. Manage., 51, 167-72.

Storch, I. (1991). Habitat fragmentation, nest site selection, and nest predation risk in capercaillie. Ornis Scand., 22, 213-17.

Storch, 1. (1993a). Habitat selection by capercaillie in summer and autumn: is bilberry important? Oecologia, Berl., 95, 257-65.

Storch, I. (1993b). Patterns and strategies of winter habitat selection in alpine capercaillie. Ecography, 16, 351-9.

Storch, I. (1993c). Habitat use and spacing of capercaillie in relation to habitat fragmentation patterns. $\mathrm{PhD}$ thesis, University of Munich.

Storch, I. (in press). The role of bilberry in central European capercaillie habitats. Proc. Int. Symp. Grouse.

Storch, I., Schwarzmüller, C. \& Von den Stemmen, D. (1991). The diet of capercaillie in the Alps: a comparison of hens and cocks. Trans. Int. Congr. Union Game Biol, 20, 630-5.

Storch, I. \& Willebrand, T. (1991). Management implications of nest and brood predation in grouse. Ornis Scand., 22, $271-2$.

Stuen, O. H. \& Spidsö, T. K. (1988). Invertebrate abundance in different forest habitats as animal food available to capercaillie chicks. Scand. J. For. Res., 3, 527-32.

Wegge, P. \& Grasaas, T. (1977). A population study of capercaillie in South Norway. Viltrapport, 5, 22-39.

Wegge, P. \& Storaas, T. (1990). Nest loss in capercaillie and black grouse in relation to the small rodent cycle in southeast Norway. Oecologia, Berl., 82, 527-30.

Wegge, P., Storaas, T. Larsen, B. B., Bö, T. \& Kolstad, M. (1982). Woodland grouse and modern forestry in Norway. A short presentation of a new telemetry project, and some preliminary results on brood movements and habitat preferences of capercaillie and black grouse. Proc. Int. Symp. Grouse, 2, 117-23. 